\title{
ANTIBACTERIAL ACTIVITY AND PHYTOCHEMICAL SCREENING OF MANGIFERA INDICA ETHANOL AND AQUEOUS LEAVES EXTRACT AGAINST PSEUDOMONAS AERUGINOSA AND STAPHYLOCOCCUS AUREUS
}

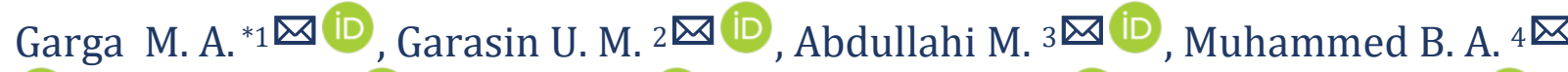

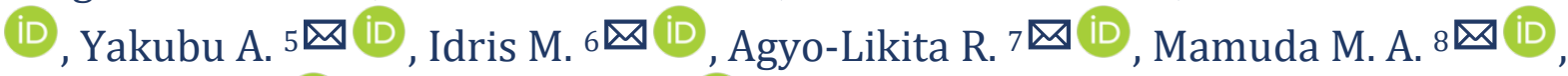
Ibrahim D. 9 (iD, Hamza L. M $10 \square$ iD

1, 2, 3, 4, 5, 6, 7, 8, 9, 10 National Biotechnology Development Agency (NABDA), Bioresources

Development Center, Katsina, No. 15 Dutsinma Road Behind Yan Katako Katsina, P.M.B 2140, Katsina State

DOI: https://doi.org/10.29121/granthaalayah.v8.i12.2020.2676

Article Type: Research Article

Article Citation: Garga M. A., Garasin U. M., Abdullahi M., Muhammed B. A., Yakubu A., Idris M., Agyo-Likita R., Mamuda M. A., Ibrahim D., and Hamza L. M. (2020). ANTIBACTERIAL ACTIVITY AND PHYTOCHEMICAL SCREENING OF MANGIFERA INDICA ETHANOL AND AQUEOUS LEAVES EXTRACT AGAINST PSEUDOMONAS AERUGINOSA AND STAPHYLOCOCCUS AUREUS. International Journal of Research GRANTHAALAYAH, 8(12), 262-269. https://doi.org/10.29121/granthaa layah.v8.i12.2020.2676

Received Date: 02 December 2020

Accepted Date: 31 December 2020

Keywords:

Antibacterial

Phytochemical

Mango

Ethanol

Aqueous

Pseudomonas

\section{ABSTRACT}

The aim of this research is to investigate the antibacterial activity and identify the phytochemical constituents of Mangifera indica leafs on Pseudomonas aeruginosa and Staphylococcus aureus using disc diffusion method. The sample was collected fresh from the premises of Bioresources Development Center (BIODEC), Katsina, Katsina State and was dried and pounded into powder. The powdered leaves were extracted using ethanol and aqueous solvents. Various concentrations ranging from $500 \mathrm{mg}$ to $62.5 \mathrm{mg}$ were prepared. Test isolates were obtained from the Microbiology laboratory, Umaru Musa Yar'adua University Katsina (UMYUK) and were further authenticated using Gram staining and biochemical test. The bacterial inoculums were standardized to McFarland scale 0.5. Zones of inhibition were read after 24 hours at 370C. The results of the antibacterial study revealed that the ethanolic leaves extracts at $500 \mathrm{mg} / \mathrm{ml}$ had effect on P. aeruginosa and S. aureus with zones of inhibition of $12 \mathrm{~mm}$ and $6 \mathrm{~mm}$ respectively. The results of the phytochemical screening revealed the presence of flavonoids, tannins, saponins, alkaloids and phenols where only alkaloids was found to be absent in the aqueous extract. There is no significant difference between the solvents and various concentrations used base on t-test data analysis. 
Garga M. A., Garasin U. M., Abdullahi M., Muhammed B. A., Yakubu A., Idris M., Agyo-Likita R., Mamuda M. A., Ibrahim D., and Hamza L. M

\section{INTRODUCTION}

\subsection{BACKGROUND OF THE STUDY}

The emergence of multi-resistant bacteria to antimicrobial drugs has increased the need for new antibiotics or modifications of older antibiotics (Tollefson and Miller 2000). One way to prevent antibiotic resistance of pathogenic species is by using new compounds that are not based on existing synthetic antimicrobial agent (Mathur et al., 2011). Reservoir of effective chemotherapeutics from plant families provides valuable sources of natural antimicrobials. For thousands of years, plant extracts have been used for a wide variety of purposes.

Cheaper and safe alternative source of drugs in this contemporary period are mostly from plant bio-resources. Modern drugs are associated with several side effects like nausea and headaches. Man has resorted to plants for treatment due to high prices of synthetic drugs. However, cases of overdose or self-poisoning through the use of medicinal plants have been increasing. The first plant compound with antimicrobial activity was reported in the 1930s (Mushore and Matuvhunye 2013) and now a multitude of plant compounds are readily available from herbal suppliers and natural-food stores. After following up on ethno-medicinal use, an estimated 74\% of pharmacologically active plant derived components were discovered. Mushore and Matuvhunye (2013) stated that more than 25\% of modern medicines are thought to have descended from plants whilst others are synthetic analogues built on prototype compounds isolated from plants. The richest bio-resource of drugs of modern medicine, folk medicine and chemical entities for synthetic drugs nowadays are from medicinal plant sources.

Mangifera indica is commonly called mango (English), mangoro (Yoruba,Nigeria), mangolo (Igbo, Nigeria), mangwaro (Hausa, Nigeria), tharyetthi (Myanmar), manguier (French), bobbiemanja, manggaboomormanja (Dutch), mamung (Thailand), manga or mango (Spanish), manga (Portuguese), manga, mempelamorampelam (Malaysia), manggaor mempelamn (Indonesia), mangobaum (German), paho (Philippines) and xoài (Vietnam) (Olasehinde et al., 2018).

\section{METHODOLOGY}

\subsection{DESCRIPTION OF STUDY AREA}

Katsina State is located between latitude $11^{\circ} 8^{\prime} \mathrm{N}$ and $13^{\circ} 22^{\prime} \mathrm{n}$ and longitude $6^{\circ} 52^{\prime} \mathrm{E}$ and $9^{\circ} 20^{\prime} \mathrm{N}$. The population of people in Katsina State is made up of 2,948,279 males and 2,853,305 females according to the 2006 National population census. Katsina falls under the dry sub-humid agro-ecological zone of Nigeria (Garga et al., 2019). According to Koppen climate classification systems, Katsina State has a semi - arid climate. The long time average of mean annual rainfall for Katsina is $789 \mathrm{~mm}$. The mean annual temperature of Katsina State is $25^{\circ} \mathrm{C}-26^{\circ} \mathrm{C}$ (Garga et al., 2019) and by the virtue of its origin, the State comprises of mostly Hausa/Fulani and other tribes.

\subsection{COLLECTION OF PLANT MATERIAL}

Mangifera indica leave is the plant material used in this study. Fresh leaves were obtained from the Bioresources Development Centre Katsina premises. The leaves were taken to the Herbarium of the Botany Unit of Biological Science Department, Umaru Musa Yaradua University, Katsina, for authentication. A voucher number UMYU 1721 was obtained and deposited at the Herbarium.

\subsection{SAMPLE PROCESSING}

Fresh leaves were washed thoroughly with clean water to remove dirt present on the plant surface. It was then shade dried for 16 days at room temperature. The plant was then oven dried at $50^{\circ} \mathrm{C}$ in an oven dryer to obtain a completely dried plant material which was later pounded into fine powder. It was then packaged into a clean polythene bag for further used (Dike Ndudim et al., 2016). 
Antibacterial Activity and Phytochemical Screening of Mangifera Indica Ethanol and Aqueous Leaves Extract Against Pseudomonas Aeruginosa and Staphylococcus Aureus

\subsection{MEDIA PREPARATION}

The media used were prepared according to the Manufacturer's instructions. The media used were Nutrient agar, Mannitol Salt agar, Mueller Hinton agar.

\subsection{SOURCE OF MICROORGANISMS}

The test isolates were obtained from the Microbiology Lab, Umaru Musa Yaradua University (UMYU) and was further authenticated using Gram staining and biochemical test.

\subsection{GRAMS STAINING AND MICROSCOPY OF THE TEST ISOLATES}

Gram staining: A thin smear of the isolates were made on different slides with the aid of a wire loop and allowed to dry and were heat fixed. Then the different smears were covered with crystal violet stain for 60seconds and rapidly washed off with clean water. Then the smears were covered with Lugol's iodine for 60seconds and rapidly washed off with clean water. The smears were decolorized rapidly with alcohol and washed out immediately with clean water. Then the smears were covered with safranin for 60 seconds and washed immediately with clean water. The stained smears were then allowed to air-dry. After drying, a few drops of oil immersion were dropped on the stained smears and viewed with the aid of a microscope $(\times 100$ oil objective lens) to check for the microscopic properties of the organisms like the Gram reaction and morphology (Garga et al., 2019).

\subsection{BIOCHEMICAL TESTS}

These were carried-out as described in the work of Garga et al. (2019).

\subsubsection{CATALASE TEST}

The discrete colonies of each of the isolates were collected with a wooden stick and emulsified in a drop of hydrogen peroxide $\left(\mathrm{H}_{2} \mathrm{O}_{2}\right)$. Bubbles of gas indicated a positive result.

\subsubsection{INDOLE TEST}

Here a little portion of each of the isolates was inoculated into $5 \mathrm{ml}$ of sterilized prepared peptone water which was contained in different test tubes using a wire loop. And then, the test tubes containing the organisms were left to incubate at $37^{\circ} \mathrm{C}$ for 48 hours. After incubation period, 3-4drops of indole reagent known as Kovac's reagent was added and shook gently. A positive result gave a red surface layer after 10 minutes.

\subsubsection{OXIDASE TEST}

A piece of filter paper was placed in a clean petri dish and 2-3drops of freshly prepared oxidase reagent was added. With the aid of a wooden stick, discrete colonies of the isolates were collected separately and smeared on the filter paper. A positive result gave a purple-blue colouration after 10 seconds.

\subsubsection{COAGULASE TEST}

A drop of distilled water was placed on each end of a slide and a colony of the test organism was emulsified in each of the drops to form a thick suspension. Then a loopful of plasma was added to one of the suspensions and swirled gently. A positive result showed clumping after 10 secconds. 
Garga M. A., Garasin U. M., Abdullahi M., Muhammed B. A., Yakubu A., Idris M., Agyo-Likita R., Mamuda M. A., Ibrahim D., and Hamza L. M

\subsubsection{CITRATE UTILIZATION TEST}

The test is based on the ability of an organism to use citrate as its only source of carbon. Simmons's citrate agar was used for the test.Simmon's citrate agar was prepared according to manufacturer's instruction and autoclaved at $121^{\circ} \mathrm{C}$ for 15 minutes. The autoclaved media was kept in a slant position and allowed to solidify. Using a sterilized straight wire loop, the slope was streaked and the butt was stabbed with a saline suspension of the test organism. This was Incubated at $37^{\circ} \mathrm{C}$ for 48 hours and observed for colour changes.

\subsection{EXTRACTION OF MANGIFERA INDICA LEAVES}

\subsubsection{PREPARATION OF AQUEOUS EXTRACTS}

Samples $(100 \mathrm{~g})$ of the dried powder of the plant leaves were soaked in $1000 \mathrm{ml}$ of distilled water contained in a $2000 \mathrm{ml}$ flask. The flask was plugged with cotton wool, wrapped with foil paper and then allowed to stand for 5 days at room temperature. The suspension was shaken vigorously and filtered using a muslin cloth. The filtrates were concentrated using a water bath at $100^{\circ} \mathrm{c}$. The concentrated extract was stored in airtight sample bottle until required. For the preparations of crude extracts for antibacterial screening, the extract was reconstituted in Dimethyl Sulphoxide (DMSO) to form $500 \mathrm{mg}, 250 \mathrm{mg}, 125 \mathrm{mg}$ and $62.5 \mathrm{mg} / \mathrm{ml}$ concentration (Olasehinde et al., 2018).

\subsubsection{PREPARATION OF ETHANOLIC EXTRACTS}

Samples $(100 \mathrm{~g})$ of the dried powdered of the plant leaves were soaked in $1000 \mathrm{ml}$ of ethanol contained in a $2000 \mathrm{ml}$ flask. The flask was plugged with cotton wool, wrapped with foil paper and then allowed to stand for 5 days at room temperature. The suspension was shaken vigorously and filtered using a muslin cloth. The filtrates were concentrated using a water bath at $100^{\circ} \mathrm{c}$. The concentrated extract was stored in airtight sample bottle until required. For the preparations of crude extracts for antibacterial screening, the extract was reconstituted in Dimethyl Sulphoxide (DMSO) to form $500 \mathrm{mg}, 250 \mathrm{mg}, 125 \mathrm{mg}$ and $62.5 \mathrm{mg} / \mathrm{ml}$ concentration (Olasehinde et al., 2018).

\subsection{DETERMINATION OF PHYTOCHEMICAL CONSTITUENTS}

This was carried out according to the method described by Bandiola, 2018.

\subsubsection{TANNINS}

The extract (50mg) is dissolved in $5 \mathrm{ml}$ of distilled water. A few drops of neutral $5 \%$ ferric chloride solution are then added. A dark green colour indicates the presence of tannins.

\subsubsection{SAPONINS}

Fifty (50mg) of extract was diluted with distilled water and made up to $20 \mathrm{ml}$. The suspension is shaken in a graduated cylinder for 15 minutes. Saponins are detected by the formation of $2 \mathrm{~cm}$ layer of foam.

\subsubsection{FLAVONOIDS}

Extract is combined with a few drops of sodium hydroxide solution. The appearance of intense yellow colour, which turns colourless on addition of dilute acid, indicates the presence of flavonoids. 
Antibacterial Activity and Phytochemical Screening of Mangifera Indica Ethanol and Aqueous Leaves Extract Against Pseudomonas Aeruginosa and Staphylococcus Aureus

\subsubsection{PHENOLS}

To zero point five $(0.5 \mathrm{~g})$ gram of extract, two $(2 \mathrm{ml})$ of distilled water was added and mixed properly. Few drops of ferric acid chloride were added. The appearance of red, purple or green colour indicates the presence of phenols.

\subsubsection{ALKALOIDS}

To a few millilitre of plant extract, two drops of Mayer's reagent (potassium mercuric iodide solution) are added along sides of the test tube. Appearance of white creamy precipitate indicates the presence of alkaloids.

\subsection{STANDARDIZATION OF THE INOCULUMS}

Standardization of the inoculums was carried out in accordance with the methods of Oyeleke and Manga (2008). Isolates were sub-cultured into fresh Nutrient Agar plates and incubated at $37^{\circ} \mathrm{C}$ for 24 hours. After the incubation, $5 \mathrm{ml}$ of sterile distilled water was placed into different universal bottles and was used to prepare the size of the inoculums. The McFarland scale of 0.5 was used which is equivalent to $150 \times 10^{6} \mathrm{cfu} / \mathrm{ml}$.

\subsection{ANTIBACTERIAL ACTIVITY OF PLANT EXTRACT}

Antibacterial screening was carried-out using disc diffusion method as described by Talba et al. (2014) with some slight modifications. Twenty milliliter $(20 \mathrm{ml})$ of sterile Mueller Hinton Agar (Hi-Media) was prepared and poured in sterile Petri plates to solidify. It was placed into the incubator at $37^{\circ} \mathrm{C}$ for 24 hours to test for media sterility. Zero point one $(0.1) \mathrm{ml}$ of the standardized inoculums was dropped onto the media using a micropipette and emulsified using sterilized bent glass. Sterile disc were placed into various concentrations of both the aqueous and ethanol extracts $(500,250,125$, and $62.5 \mathrm{mg} / \mathrm{ml})$ using a sterilized forceps respectively. It was then allowed to stand for 30 minutes. Antibiotic discs were aseptically placed over the Mueller-Hinton agar, the test was repeated in duplicate. The discs were sufficiently separated from each other to avoid overlapping of inhibition zones. Ciprofloxacin $\left(250 \mathrm{mg}\right.$ ) was used as control drug for the test bacteria. The plates were incubated at $37^{\circ} \mathrm{C}$ for 24 hours. Zones of inhibitions recorded in millimeter ( $\mathrm{mm})$.

\subsection{DETERMINATION OF MIC USING BROTH DILUTION METHOD}

MIC values were determined by broth dilution assay. Sterile plant extracts were serially diluted (two-fold) to obtain a concentration range of $500 \mathrm{mg} / \mathrm{ml}$ to $62.5 \mathrm{mg} / \mathrm{ml}$. Then, $0.1 \mathrm{ml}$ of each concentration was added to $9 \mathrm{ml}$ of nutrient broth containing $0.1 \mathrm{ml}$ of standardized test organism of bacterial cells. Negative controls were equally set up by using solvents and test organisms without extracts. Tubes with culture medium only were set as controls for sterility of the medium. Test tubes were evaluated for the presence or absence of visible turbidity in the broth after the incubation period. Lowest concentration (highest dilution) of the extract preventing appearance of turbidity (growth) was considered and recorded as the MIC (Garga et al., 2019). Ciprofloxacin was used as a positive control.

\subsection{DETERMINATION OF MBC}

From the tubes showing no visible sign of growth/turbidity in MIC, zero point one (0.1) $\mathrm{ml}$ of the sample was inoculated onto sterile nutrient agar using the streak plate method. The plates were then incubated at $37^{\circ} \mathrm{C}$ for 24 hours. The least concentration that did not show growth of the test organism was considered as the MBC (Mushore and Matuvhunye 2013). Plate with media only was set as a negative control to check the sterility of the media.

\section{RESULTS AND DISCUSSION}

Results of the antibacterial activity of the crude Mango ethanol and aqueous leaf extracts on the test bacteria are presented in Table 4.1. The result shows that both ethanol and aqueous mango leaves extract were active against 
Garga M. A., Garasin U. M., Abdullahi M., Muhammed B. A., Yakubu A., Idris M., Agyo-Likita R., Mamuda M. A., Ibrahim D., and Hamza L. M

the test bacteria at various concentrations. The highest zone of inhibition (ZOI) recorded was on Pseudomonas aeruginosa (PSA) at concentration of $500 \mathrm{mg} / \mathrm{ml}$ aqueous extract while the lowest (ZOI) recorded was on Staphylococcus aureus (STA) at $62.5 \mathrm{mg} / \mathrm{ml}$ concentration of aqueous extracts.

Table 3.1: Antibacterial Activity of Mango Ethanol and Aqueous Leaf Crude Extracts Against Test Bacteria

\begin{tabular}{|c|c|c|}
\hline & $\begin{array}{c}\text { Zones of inhibition of extracts in (mm)/Bacteria } \\
\text { tested }\end{array}$ & $\begin{array}{c}\text { MLAE } \\
\text { STA(Mean } \pm \text { S.D) }\end{array}$ \\
\hline Conc. of extracts in $\mathrm{mg} / \mathrm{ml}$ & $\begin{array}{c}\text { MLEE } \\
\text { PSA(Mean } \pm \text { S.D) }\end{array}$ & $6 \pm 0.00$ \\
\hline $500 \mathrm{mg}$ & $12 \pm 7.52$ & $4 \pm 3.53$ \\
\hline $250 \mathrm{mg}$ & $9 \pm 3.54$ & $1 \pm 0.71$ \\
\hline $125 \mathrm{mg}$ & $7 \pm 5.52$ & $0 \pm 0.00$ \\
\hline $62.5 \mathrm{mg}$ & $1 \pm 0.00$ & 35 \\
\hline Control (Ciprofloxacin & 37 & \\
\hline
\end{tabular}

\section{KEY}

MLEE = Mango leaf ethanol extract

MLAE = Mango leaf aqueous extract

PSA = Pseudomonas aeruginosa

STA = Staphylococcus aureus

S.D = Standard Deviation

Result of phytochemical screening of Mango leaf ethanol and aqueous extracts is presented in Table 3.2. The result shows the presence of tannin, phenols, saponin, alkaloid, and flavonoid in both MLEE and MLAE while only alkaloid was absent in MLAE.

Table 3.2: Phytochemical Screening of Mango leaf ethanol and aqueous extracts

\begin{tabular}{|c|c|c|c|c|c|}
\hline Phytochemicals & Tannin & Phenols & Saponin & Alkaloid & Flavonoid \\
\hline Crude extracts & & & & & \\
\hline MLEE & + & + & + & + & + \\
\hline MLAE & + & + & + & - & + \\
\hline
\end{tabular}

\section{KEY}

MLEE= Mango leaf ethanol extract

MLAE $=$ Mango leaf aqueous extract

\subsection{DISCUSSION}

Crude antibacterial activity for both ethanol and aqueous mango leaves extract in this study reveals that all the test bacteria were susceptible to both the extracts at $500 \mathrm{mg} / \mathrm{ml}, 250 \mathrm{mg} / \mathrm{ml}$, and $125 \mathrm{mg} / \mathrm{ml}$ concentrations on Pseudomonas aeruginosa and Staphylococcus aureus but with the exception of $62.5 \mathrm{mg}$ concentration of mango leave aqueous extract on Staphylococcus aureus which shows resistance. Zone of inhibition of MLEE against PSA were $12 \pm 7.52 \mathrm{~mm}, 9 \pm 3.54 \mathrm{~mm}, 7 \pm 5.52 \mathrm{~mm}$, and $1 \pm 0.00 \mathrm{~mm}$ while that of STA were $6 \pm 0.00 \mathrm{~mm}, 4 \pm 3.53 \mathrm{~mm}, 1 \pm 0.71 \mathrm{~mm}$ and $0 \pm 0.00 \mathrm{~mm}$ at $500 \mathrm{mg} / \mathrm{ml}, 250 \mathrm{mg} / \mathrm{ml}, 125 \mathrm{mg} / \mathrm{ml}$ and $62.5 \mathrm{mg} / \mathrm{ml}$ respectively. This indicates that the susceptibility of all the test bacteria to both ethanol and aqueous extracts starts from $62.5 \mathrm{mg}$ up to $500 \mathrm{mg}$ concentrations which demonstrates that the higher the concentration of both the extracts, the higher the antibacterial activity, thus, the extract exhibit concentration dependent activity. This result is similar with the work of Mada et al. (2012) who showed that PSA at $200 \mathrm{mg} / \mathrm{ml}, 100 \mathrm{mg} / \mathrm{ml}$ and $50 \mathrm{mg} / \mathrm{ml}$ had zones of inhibition of $17 \mathrm{~mm}, 15 \mathrm{~mm}$ and $10 \mathrm{~mm}$ while that of STA also at $200 \mathrm{mg} / \mathrm{ml}, 100 \mathrm{mg} / \mathrm{ml}$ and $50 \mathrm{mg} / \mathrm{ml}$ had zones of inhibition of $19 \mathrm{~mm}, 17 \mathrm{~mm}$ and $14 \mathrm{~mm}$ respectively. The result is also in line with the work of Hannan et al. (2013) who showed zone of inhibition of acetone mango leaf extract against STA and multi-drug resistant Salmonella typhi to be 20, 22, 24, 26 and $26 \mathrm{~mm}$ and 15.25, $17,17.5,18.25$ and 19.75 at 50, 100, 200, and $250 \mathrm{mg} / \mathrm{ml}$ respectively. 
Result of the minimum inhibitory concentration (MIC) for both aqueous and ethanol extracts on STA and PSA was found to be at $125 \mathrm{mg} / \mathrm{ml}$. This finding is in line with the work of Olasehinde et al. (2018) who showed the MIC of the extract on STA and PSA to be at $125 \mathrm{mg} / \mathrm{ml}$ and $250 \mathrm{mg} / \mathrm{ml}$ respectively. The MBC result in this study for both aqueous and ethanol extract on STA and PSA was found to be at $250 \mathrm{mg} / \mathrm{ml}$. This finding is in line with the work of Chukudebe et al. (2019) who showed the MBC of PSA to be at $200 \mathrm{mg} / \mathrm{ml}$. Taddaow et al. (2018) reported the MBC of STA and Methicillin Resistant Staphylococcus aureus to be at $31.25 \mathrm{mg} / \mathrm{ml}$ and $62.25 \mathrm{mg} / \mathrm{ml}$ respectively. This implies that the extracts have bacteriostatic effect on the test bacteria while the MBC indicates bactericidal effect on the test bacteria.

Result of phytochemical constituents in the mango leaf extract reveals the presence of flavonoid, alkaloid, tannin, saponin and phenols. Presence of saponin and tannin is similar to the work of Doughari and Manzara (2008). Presence of flavonoids, alkaloids and phenols is in line with the work of Diso et al. (2017). The implication of these findings is that bioactive compounds are believed to be responsible for the observed antibacterial activity of the plant extracts.

\section{CONCLUSION}

The results obtained in this study have shown that the leaves of Mangifera indica exhibit antibacterial activity with both ethanol and aqueous extracts. The mango leaves showed phytoconstituents such as flavonoids, alkaloids, saponin, tannins and phenols which were claimed to be responsible for the antibacterial activity on the test bacteria.

\section{SOURCES OF FUNDING}

This research received no specific grant from any funding agency in the public, commercial, or not-for-profit sectors.

\section{CONFLICT OF INTEREST}

The author have declared that no competing interests exist.

\section{ACKNOWLEDGMENT}

None.

\section{REFERENCES}

[1] Bandiola, T. M. (2018). Extraction and Qualitative Phytochemical Screening of Medicinal Plants, International Journal of Pharmacy, 8(1)137-140.

[2] Chukudebe, E. P. Bankole, S. O., Asonibare, A.0 \& Adedokun, S.A. (2019). Antimicrobial \& Phytochemical Properties of Crude Extracts of Some Selected Plants Agents on Some Microbial Isolates, Internal Journal of Agriculture, Environment \& Bioresearch 4(5): 2456-8643.

[3] Cheesbrough L., Bard, BM., Parker, TC., and Gould, GW. (2006). District Laboratory Practice in Tropical Countries. Part 2. Published by Cambridge Universities Press. Pp 38-39;64-70.

[4] Doughari, J. H., and Manzara, S. (2008). In vitro Antibacterial Activity of Crude Leaf Extracts of Mangifera indica Linn. African Journalof Microbiology Research 2:67-72.

[5] Dike-Ndudim, J.N., Anyanwu, G.O., Egbuobi, R.C., Okorie, H.M., Udujih, H.I., Nwosu, D.C., and Okolie, N.J.C. (2016). Antibacterial and Phytochemical Potential of Moringa oleifera Leaf Extracts on some Wound and Enteric Pathogenic Bacteria, European Journal of Botany, Plant Sciences and Phytology, 3(1): 50-6

[6] Diso, S.U., M. Ali, S.I. Mukhtar, and Garba, M. (2017). Antibacterial Activity and Phytochemical Screening of Mangifera indica (mango) Stem and Leaf Extracts on Clinical Isolates of Methicillin Resistant Staph aureus, Journal of Advanced Medical and pharmaceutical science. 13 (1):1-6 
Garga M. A., Garasin U. M., Abdullahi M., Muhammed B. A., Yakubu A., Idris M., Agyo-Likita R., Mamuda M. A., Ibrahim D., and Hamza L. M

[7] Garga, M. A., Manga, S. B., Rabah, A. B., Tahir, H., Abdullahi, M., Ahmed, M., Abdullahi, H. A., Bako, I., Abdurrahman, S. A., and Mukhtar, U. F. (2019). Antibacterial Activity and Phytochemical Screening of Moringa oleifera Lam. Leaves and Seeds Extracts on Staphylococcus aureus, International Journal of ResearchGraanthaalayah, 7(11): 276-284. https://dio.org/10.5281/zendio.3571982.

[8] Hannan, A., Asghar, S., Naeem, T., Ullah, MI., Ahmed, I., Aneela, S., and Hussain, S. (2013). Antibacterial effect of Mango (Mangifera indica Linn.) leaf extract against antibiotic sensitive and Multi-drug resistant Salmonella typhi, Pakistan Journal of Pharmaceutical Sciences, 26 (4): 715-719

[9] Mathur, A., Singh, R., Yousuf, S., Apraiita, B., Satish, K. (2011). Antifungal Activity of some Plant Extracts Against Clinical Pathogens, Advances in Applied Sciences Research, 2(2): 260-264

[10] Mushore, J., and Matuvhunye T. (2013). Antibacterial Properties of Mangifera indica on Staphylococcus aureus, African Journal of Clinical and Experimental Microbiology, 14(2): 62-74

[11] Mada SB. Garba, A., Mohammed, HA., Muhammad, A., and Olaguniu AB. (2013). Antimicrobial activity and phytochemical screening of aqueous and ethanol extracts of Momordica charantia L. Leaves, Jounal of Medicinal Plants Researc,. 7(10): 579-586.

[12] Olasenhinde G.I, Sholotan K.J., Openibo J.O, Taiwo O. S., Bello O. A, Ajayi J.B., Ayepola 0.O. and Ajayi A.A. (2018). Phytochemical \& Antimicrobial properties of Mangifera indica Leaf Extracts, Convenant Journal of Physical \& Life Sciences, 6 (1):55-63

[13] Oyeleke, S.B. and Manga, S.B. (2008). Essentials of Laboratory Practicals in Microbiology. Niger,TOBEST PUBLISHER,93-99

[14] Taddaow K., Supap, Saenphet, Yingmance T. \& Kanokporn, S. (2018). Antibacterial Effects of Thai Mango (Mangifera indica Linn) Leaves Against Acne-inducing Bacteria, Science International Journal. 30(3) :449-453

[15] Talba, M. A., Suleiman, M. M., Abiola, R., Oniye, S. (2014). Phytochemical Screening and in vitro Antibacterial Activity of Mangifera indica (Mango) Kernel on Aeromonas caviae, IOSR Journal of Pharmacy, 4(10): 45-50.

[16] Tollefson, L., and Miller, A. M. (2000). Antibiotic use in Food Animals: Controlling the Human Heath Impact, Journal of AOAC International, 83(2): 245-54 